\title{
Nonideal Justice as Nonideal Fairness
}

\begin{abstract}
This article argues that diverse theorists have reasons to theorize about fairness in nonideal conditions, including theorists who reject fairness in ideal theory. It then develops a new all-purpose model of 'nonideal fairness'. Section I argues that fairness is central to nonideal theory across diverse ideological and methodological frameworks. Section 2 then argues that 'nonideal fairness' is best modeled by a nonideal original position adaptable to different nonideal conditions and background normative frameworks (including anti-Rawlsian ones). Section 3 argues that the parties to the model have grounds to seek a variety of remedial social, legal, cultural, and economic 'nonideal primary goods' for combating injustice as well as grounds to distribute these goods in an equitable and inclusive manner. Finally, I illustrate how the model indexes the nonideal primary goods it justifies to different nonideal contexts and background normative frameworks, illustrating why diverse theorists should find the model and its output principles attractive.
\end{abstract}

KEYWORDS: justice, fairness, ideal theory, nonideal theory, original position

Moral, social, and political theorists have increasingly focused on the distinction between ideal and nonideal theory-and for good reason. First, it is vital to determine whether we should theorize about ideals-as many allege ideal theorizing is inherently problematic (Farrelly 2007; Mills 2005; Sen 2009; Wiens 20I 5; cf. Lawford-Smith 20I0; Simmons 20I0; Erman and Möller 20I3; Volacu 20I8). Second, if ideal theorizing should be done, there are questions of how to do it properly and distinguish it from nonideal theory (Rawls I999a: 4-5, 2I5-I7; Stemplowska 2008; Simmons 20IO; Valentini 20I2; Volacu 20I8). Third, there is the issue of how to extend ideal theories to nonideal conditions, both generally (Arvan 2008, 20I4; Mills 20I7: 20I-I6; Phillips 1985; Simmons 20I0; Volacu 20I8) and for specific issues, such as affirmative action (Taylor 2009; Matthew 20I5), reparations (Carcien 20IO; Espindola and Vaca 20I4), and warfare (Rawls I999b: part 2). Finally, if ideal theorizing should not be pursued, there is the question of how to theorize properly without it (Sen 2009; Wiens 20I 2).

Although substantial progress has been made on these questions, this article argues that two issues remain underexplored: the extent to which fairness should be central to nonideal theorizing, and how to theorize about 'nonideal fairness' properly. This article argues that diverse theorists have reasons to theorize about

I thank my colleagues M. L. Arvan, Steven Geisz, and Laura Kane for their invaluable feedback and support. I am also grateful to Helen De Cruz, two reviewers, and the editors of the Journal of the American Philosophical Association. Finally, I thank Thomas Christiano and Gerald Gaus for guidance in the early stages of this project many years ago. 
nonideal fairness. It then defends a new all-purpose framework for determining what nonideal fairness requires.

Section I argues that fairness is central to nonideal theory across diverse ideological and methodological frameworks. First, section I.I argues that fairness is central to Rawlsian nonideal theory. Section I.2 then argues that fairness remains central to nonideal theory for two very different ideologies: Nozickean libertarianism and Marxism. Here I show that although Nozick rejects fairness in ideal theory, he invokes it in nonideal theory because only fairness appears capable of resolving conflicts in his theory of rectification. I then show that an analogous point extends to Marxism. Finally, section I.3 argues that the point extends to the 'nonideal-theory-only' approaches defended by Sen and Wiens. Although section I addresses only a handful of theoretical frameworks, I use them because they are influential and ideologically as well as methodologically diverse-and because they illustrate a general point: that nonideal conditions give rise to conflicting claims that fairness appears necessary to resolve adequately. Accordingly, although section I does not establish that all theories of justice require an account of nonideal fairness, it shows that several diverse and influential frameworks do; that nonideal fairness has been undertheorized across those frameworks; and that there are general reasons to think this may be true of other (if not all $)^{\mathrm{I}}$ normative frameworks.

Next, section 2 argues that a quasi-Rawlsian model of fairness applied to nonideal conditions-a generalized version of a 'nonideal original position' previously defended in a Rawlsian context-models a conception of nonideal fairness that diverse theorists should find attractive. Readers may note similarities to Mills's (20I7: epilogue, esp. 2I3) suggestion that liberalism should utilize a modified Rawlsian model to address racial injustice. However, there are important differences between our projects. First, my project is broader, arguing that a modified Rawlsian model should be utilized by more diverse theorists, including libertarians, Marxists, and those who disagree with Mills's (I997, 2005) critiques of ideal theory. Second, the modified Rawlsian apparatus defended here is a generalized form of the model previously defended in Arvan (2008, 20I4), where I argue it has different implications for racial justice than Mills (20I7: 2I4-I5) suggests.

Finally, section 3 explores principles of nonideal justice that might emerge from the model-principles I suggest diverse theorists should find attractive as well.

\section{Fairness as Central to Nonideal Theory}

Some contend that justice is fairness, understanding justice in terms of substantive principles of fairness justified by a fair procedure (Rawls I999a: \$3; Dworkin

\footnotetext{
${ }^{\text {I }}$ As one reviewer noted, utilitarianism is a plausible counterexample: whether it supports 'nonideal fairness' depends on what maximizes utility. Although this is true, Rawls's influential objection to utilitarianism-that it fails to respect the 'separateness of persons' (Rawls I999a: 23, I63)-may be instructive. One possibility worth examining is whether fairness is central to nonideal theory for any normative framework that adequately respects separateness of persons. However, we must set this aside for future inquiry.
} 
2002). However, not everyone does. Libertarians identify an ideally just order as respecting liberty (Nozick I974: chs. 2-8, esp. 90-95), and classical utilitarians contend justice involves maximizing the good (Mill [I86I] 200I: ch. 5)—even though both arguably justify unfair treatment (Rawls I999a: \$5; Nozick I974: chs. 7-8). Thus, justice and fairness may or may not be identical. Nevertheless, questions of procedural and substantive fairness loom large in nonideal contexts. For example, is affirmative action just? Proponents argue justice requires or permits it for ensuring fair outcomes (Appiah 201 I; Beauchamp I998; Burns and Schapper 2008) or fair selection-procedures (Harris and Narayan I994). However, opponents allege that it is an unfair procedure of reverse discrimination (Pojman I998; Taylor 2009; Mulligan 20I7). Is universal health care just? Proponents often argue fairness requires it (Daniels I985; Dworkin I993); others disagree (Jacobs 1996). What about reparations for historical injustice? Proponents often argue that fairness substantively requires reparations (Carcien 20IO; Espindola and Vaca 20I4; Coates 20I4). However, opponents allege that reparations are an unfair procedure harming the innocent (Horowitz 200I). And world poverty? Some argue fairness requires a lot from people to alleviate it (Singer I972); others are less certain (Arvan 2016: I94-96; Wenar 2003).

I will not argue here that fairness is the only normative issue in nonideal theory (cf. Arvan 20I6). The relevant point is that fairness is normatively central to debates about justice in a nonideal world. We will now see there are good reasons why.

\section{I.I Fairness in Rawlsian Nonideal Theory}

Given that Rawls holds that justice is fairness, fairness is surely central to Rawlsian nonideal theory. What is less well-understood is what Rawlsians should take 'nonideal fairness' to be. Some contend that Rawls's principles of ideal justice should be extended to nonideal conditions 'in spirit' (Korsgaard I996: I47-5I; Taylor 2009). Further, some who presuppose this approach suggest that nonideal theory cannot save Rawls's ideal theory from common critiques (Kang 20I6). These views, however, are mistaken. As Simmons (20I0: $\mathbb{3}$ ) and I (Arvan 20I4: 97-IOI) argue, Rawls's ideal theory cannot be extended to nonideal conditions straightforwardly, but when it is extended properly, it can address issues not addressed adequately in ideal theory and (contra Kang) afford extra concern for the interests of marginalized groups (Arvan 20I4: I I4-I 5). Allow me to explain.

Earlier (Arvan 20I4), I argued that because Rawls assumes 'strict-compliance' in ideal theory, Rawlsian ideal theory generates no account of what fairness requires under nonideal conditions. Rawls recognized this lacuna:

It will be recalled that strict compliance is one of the stipulations to the original position. . . . Because the parties are choosing a conception of justice suitable for favorable conditions ... the principles [of justice] define then a perfectly just scheme. . . But even granting the soundness of these principles for this purpose, we must still ask how well they apply to institutions under less than favorable conditions, 
and whether they provide any guidance for instances of injustice. The principles and their lexical order were not acknowledged with these situations in mind and so it is possible that they no longer hold. (Rawls I999a: 2I 5-I6; emphasis added)

Specifically, in his theory of domestic justice, Rawls has the parties to the original position assume theirs is 'a society in which (I) everyone accepts and knows that others accept the same principles of justice, and (2) the basic social institutions generally satisfy and are known to satisfy these principles' (I999a: 4). Simmons (20I0: I7) shows this assumption entails two possible types of domestic noncompliance: noncompliance by individuals and by institutions. To see how Rawlsian ideal theory thus fails to provide an analysis of nonideal fairness, consider one case of institutional noncompliance: the present-day United States. The United States fails to comply strictly with Rawls's first principle of ideal justice. For although the US Constitution nominally ascribes equal basic rights and liberties to all citizens-in conformity with Rawls's first principle- the United States fails to satisfy that principle's requirement that everyone enjoy the 'fair value' of those rights and liberties (Rawls I993: 358; Rawls 200I: I49; see also Krishnamurthy 20I2, 20I3). Some ways the United States plausibly fails to do so include voter suppression (Bentele and O'Brien 20I3) and evisceration of the Fourth Amendment for minority populations (Alexander 20I2: ch. 2). The United States also fails to satisfy Rawls's principle of fair equality of opportunity, which plausibly prohibits (Rawls I999b: 63, 245) the vast disparities in the United States by race and ethnicity in education (Mickelson 2003), health care (Williams and Jackson 2005), incarceration (Pettit and Western 2004), and so on. Finally, the United States fails to satisfy Rawls's (I999a: 65-68) difference principle, which prohibits economic inequalities not to the advantage of all, particularly the least well-off-as economic inequality in the United States primarily benefits the top I percent (Piketty and Saez 2006).

None of this is surprising. If Rawls's ideal theory of domestic justice is correct, the United States must change substantially to become fully just. But at what cost and to whose cost? Consider one attempt to arguably move closer to Rawls's ideal of fair equality of opportunity: the Affordable Care Act of 20I0, the nominal aim of which is to ensure that all Americans have access to affordable health care. Suppose the ACA brought the United States closer to Rawlsian ideals. Regardless, transition to the ACA imposed costs on people that would never arise in an ideal Rawlsian society. Among other things, businesses and insurance companies had to take on costs of unhealthy individuals who might have been healthier if the United States had had a just health care system from the outset (see Kocher and Adashi 20II). The point here is simple: nonideal conditions generate 'nonideal costs' that would never arise under ideal conditions-costs of injustice and costs of reform.

This is critical. Because of Rawls's strict compliance assumption, the parties to his ideal original position never considered any such costs, including costs from individual noncompliance. Consequently, if justice is fairness (as Rawls contends), Rawlsians still need to provide some further account of nonideal fairness that factors in nonideal costs. Finally, because Rawls similarly predicates his Law of 
Peoples (I999b: 3) on strict compliance, Rawlsians need a theory of nonideal fairness for international affairs as well (Simmons 2010: I7; cf. Arvan 2008).

\section{I.2 Fairness in Non-Rawlsian Nonideal Theory}

This article cannot examine every ideological perspective. Instead, let us examine two deeply opposed ideologies: Nozickean libertarianism and Marxism. As we will now see, both also generate clear reasons to theorize about nonideal fairness in ways not yet fully recognized. Along with Rawlsianism, I use these test cases to illustrate that across diverse and opposing ideologies, nonideal conditions give rise to conflicting claims that fairness appears necessary to adequately resolve.

Let us begin with Robert Nozick's libertarian theory. Nozick (I974: 28-34) defends negative rights to life, liberty, and property as moral 'side-constraints' that cannot be permissibly violated even for protecting the same rights of others. He then argues that only a 'minimal' libertarian state respects these constraints (I974: chs. 4-9). Throughout, Nozick inveighs against the idea that justice is a matter of fairness, at least in ideal theory. First, he argues against fair play-the notion (see Hart I955; Rawls I964) that persons benefitting from mutually advantageous cooperative ventures (such as a nation-state) owe acquiescence to the venture's rules as a matter of fairness. Second, Nozick (1974: ch. 7) argues against a 'fair distribution' of wealth and income, contending that justice requires respect for individual property rights. Finally, Nozick argues against entitlements to fair equality of opportunity, meaningful work, and nonexploitation (I974: ch. 8). Given Nozick's systematic opposition to fairness in ideal theory, why should a Nozickean ascribe normative force to fairness in nonideal theory?

The answer, surprisingly, is in Anarchy, State, and Utopia (Nozick I974). First, on the few occasions that Nozick discusses nonideal theory, considerations of fairness are prominent. Consider Nozick's answer to what justice requires in rectifying historical injustice. Nozick claims we should reason counterfactually, asking which property holdings individuals would have if injustice never occurred (I974: I 52-53). However, Nozick then adds:

Whatever difficulties [one] has in applying the principle of rectification to persons who did not violate the first two principles [of the entitlement theory of justice] are difficulties in balancing considerations so as to correctly formulate the complex principle itself. (I974: I73)

If 'balancing considerations' sounds like fairness, that is because it is. Later, Nozick argues that because we cannot determinately trace the effects of historically distant injustices (e.g., we cannot know precisely which individual or individuals would hold this land had Native Peoples never been defrauded), we must appeal to some other normative notion beyond respect for liberty. And that notion? Nozick writes:

Perhaps it is best to view some patterned principles of distributive justice as rough rules of thumb meant to approximate the general results of 
applying the principle of rectification. ... For example, lacking much historical information, and assuming (I) that victims of injustice generally do worse than they otherwise would and (2) that those from the least well-off group ... have the highest probability of being the (descendants of) victims .... then a rough rule of thumb for rectifying injustices might seem to be the following: organize society so as to maximize the position of whatever group ends up least well-off in society.... Although to introduce socialism as the punishment for our sins would be to go too far, past injustices might be so great as to make necessary in the short run a more extensive state in order to rectify them. (1974: 230-3 I, emphases added)

In essence, Nozick holds that when we lack sufficient information to rectify past injustices counterfactually (viz. respect for individual liberty), we must appeal to fairness, instituting something like Rawls's difference principle because it seems the fairest thing to do. Fairness also seems implicit in Nozick's addendum that socialism 'would go too far.' Why would it 'go too far'? What answer can Nozick plausibly give here except, 'That amount of infringement of liberty would be unfair'?

Second, by investigating the normative foundations Nozick gives for libertarianism, we can see that there are independent reasons to think he must invoke fairness in nonideal conditions. Nozick gives two justifications for libertarian side-constraints. First, Nozick (1974:32) suggests that they are perhaps the best interpretation of the Kant's ([I785] I996: 4:429) requirement never to treat humanity as a mere means (cf. Rawls I999a: $\$ 40$ ). Nozick's second justification focuses on our ability to plan our lives and pursue our ends. $\mathrm{He}$ contends that insofar as these things enable us to make our lives meaningful (Nozick I974: 48-5I), and we care about living meaningful lives-not merely pleasant ones $(42-45)$-we have moral grounds to treat liberty as a side-constraint.

We can see how both rationales apply to Nozick's (93-94) public address example against fair play. Nozick asks whether, even if you enjoyed others playing a public address system, justice permits others to coerce you to play it on 'your' assigned day. Nozick claims this would be unjust, as it would deprive you of your liberty (94-95). Regardless of whether we agree, we can see how Nozick's two rationales for libertarian side-constraints apply: in his view, forcing you to play the address system would use you as a mere means for others, making you spend one day of your life doing something you do not find meaningful.

However, can Nozick's normative rationales coherently justify libertarian side-constraints in nonideal conditions? It is hard to see how. Consider slavery or historical injustices toward Native Peoples, the downstream effects of which are still pervasive (see my discussion earlier regarding systemic inequalities of basic liberties, opportunities, and income in the United States, at least some of which surely reflect historical injustice on Nozick's libertarian picture). For Nozick, historical injustices invalidate any resulting distribution of property holdings. For example, if someone's ancestor was unjustly deprived of this land, then for Nozick no one other than the original holder or their descendants is morally entitled to it. Here, though, is the problem. If we do not know who would have been entitled to 
this land if no injustice had occurred, then Nozick's counterfactual account of rectification cannot specify who is now entitled to the land. On the one hand, some people (descendants of Native Peoples, slaves, etc.) remain disadvantaged by historical injustice, compromising their ability to pursue their life plans freely in ways that (for all we know) they might be counterfactually entitled to. On the other hand, taking land or property away from you or me would interfere with our autonomy and life plans in ways we may be counterfactually entitled to. Because in cases of distant injustice we cannot know precisely who is counterfactually entitled to what, Nozick's principle of rectification-his account of what respect for liberty requires in rectifying injustice-cannot specify what nonideal justice requires. But if liberty cannot settle this, what can? As Nozick's own discussion reveals, only some notion of fairness-some notion of how much liberty it is fair for people to sacrifice to rectify distant injustices-appears capable of specifying which forms of rectification 'go too far' and which do not.

Now consider Communism-the Marxist notion that an ideal, nonexploitative society would distribute goods from each according to their ability and to each according to their need (Marx [I89I] 2008: part I). Although Marx's theory of history ('dialectical materialism') holds that Communism must be achieved through a proletarian revolution, Marxism still implies an 'ideal theory' of sorts. After all, Marx's complaint against all non-Communist systems is that they are unfairly exploitative (Marx [I 89I] 2008; Marx and Engels [I 848] 2009; cf. Elster I978). Insofar as Marx argues that Communism is normatively superior to other social-political systems, Marxism implies that Communism is ideal.

We can now see in turn why Marxists should theorize about 'nonideal fairness'. One reason is the astonishing unfairness and brutality of past and present 'Communist' movements, such as mass murder and starvation in Soviet Russia following the Bolshevik Revolution (Rappaport I999: 53), the great famine resulting from Mao's Great Leap Forward (Song 2010), and so on. Of course, many might contend that Leninism, Stalinism, and Maoism misinterpreted or misapplied Marxism. However, this does not obviate the need for a theory of nonideal fairness for Marxists, for two reasons. First, because different interpretations of Marxism can be held and have been pursued at great human cost, a nonideal theory of fairness for those interpretations might have helped to prevent immense atrocities-by getting Leninists, Maoists, and so on to understand that their ideals do not justify any and every means for achieving them. Second, Marx's own theory of a proletarian revolution lacks an adequate account of the costs people should face in the transition to Communism. Given Marx's normative opposition to unfair exploitation, moral consistency requires applying the same standard to social transition: a Marxist conception of 'nonideal fairness' (which I explore in section 3 ).

Thus, across diverse frameworks-Rawlsianism, Nozickean libertarianism, and Marxism-we observe similar issues. First, because each framework's ideals abstract away from 'nonideal costs', each tradition needs to provide a normatively coherent and plausible account of how nonideal costs should be addressed. Second, we have seen that on all three frameworks, only fairness appears capable of fulfilling this role-because 'nonideal costs' give rise to conflicting claims that 
other notions (like liberty) appear normatively insufficient to resolve. Finally, we can see how the argument plausibly extends to other ideal theories. Insofar as ideal theories focus on ideal conditions-abstracting away from nonideal costs and the conflicting claims they generate-normatively forceful questions about nonideal fairness seem likely arise relative to other ideal theories as well.

\section{I.3 Fairness in Nonideal-Theory-Only Frameworks}

Similar issues arise even for 'nonideal-theory-only' approaches to social and political theory. For example, Amartya Sen (2009) argues for reasoning about justice using comparative judgments, normatively evaluating actions and institutions based on their effects on human capabilities. Similarly, Wiens (20I2) argues for focusing on institutional failure analysis-that is, on ways institutions generate problematic social outcomes and ways to correct such failures. However, these accounts also need some further account of nonideal fairness.

To see how, suppose we judge the current US health care system to be comparatively worse than universal health care (qua Sen), perhaps because current institutions generate problematic outcomes (qua Wiens). Nevertheless, any transition to a system of universal health care is going to impose costs on people, such as shifting tax burdens, putting insurance companies out of business, insurance adjusters out of jobs, and so on. These costs raise questions of fairness not adequately addressed by Sen's or Wiens's methods. First, there are questions of fairness in weighing 'comparatively better states of affairs' or 'better institutions' against transition costs. Second, there are questions of fairness in distribution-of how transition costs should be distributed across individuals, groups, or nations in social reform. Consequently, nonideal-theory-only theorists also need a further theory of nonideal fairness: a theory of the costs it is fair to impose upon people for bringing about a comparatively better world.

\section{Nonideal Justice as Nonideal Fairness}

We have seen that diverse theoretical traditions need an account of nonideal fairness. Nonideal conditions give rise to 'nonideal costs' — to conflicting claims inadequately addressed in ideal theory or by standard 'nonideal-theory-only' methods-that fairness appears normatively necessary to resolve. However, what would a compelling analysis of nonideal fairness look like?

Intuitively, such an analysis needs to do several things. First, it should hold everyone in nonideal conditions to whichever duties of justice we might conditionally establish prior to factoring 'nonideal costs'. Such duties may be specified in two ways. First, they might be specified by ideal theory. As we have seen, ideal theories define ideal conditions by abstracting away from nonideal costs: Rawls derives his principles of ideal justice from an assumption of strict compliance; Nozick derives his ideal libertarian state from the assumption that libertarian side-constraints are never violated, and so on. Because ideal theories abstract away from nonideal costs, they at most establish conditional dutiesduties to bring about ideal conditions (relative to whichever ideal theory is 
assumed) all things being equal. Alternatively, if ideal theory is rejected, conditional duties may be arrived at through 'nonideal-theory-only' methods-for instance, through Sen's method of comparative evaluation or Wiens's analysis of institutional failure. However, as we saw in section I.3, these methods also only establish conditional duties of justice. Sen's method at most specifies which end-states would be comparatively more just (abstracting away from transition costs), and Wiens's method only tells us which institutions are failing and which institutions might work better (not which transition costs are fair to impose upon people). Consequently, a good model of nonideal fairness should not only include or 'plug in' whichever conditional duties of justice are established by other methods. It should also (I) model a fair procedure for, (2) weighing such conditional duties against 'nonideal costs', and for (3) justifying substantive conclusions about what fairness requires in nonideal conditions taking these matters into consideration.

Such a model, if constructed, would appear to comprise a compelling all-purpose analysis of nonideal fairness for two reasons:

I. It could be attached fruitfully to a diverse variety of ideological or methodological frameworks, inserting whichever conditional duties one's favored theoretical framework affirms.

2. It would constitute a fair procedure for arriving at substantive principles of nonideal fairness on two critical issues we have seen other frameworks elide: (i) fairness in weighing conditional duties of justice against nonideal costs (and, by extension, weighing nonideal costs against each other), and (ii) fairness in distributing nonideal costs in social reform.

Can we construct such a model? In Arvan (20I4), I argued that a variant of Rawls's original position-a 'nonideal original position'-does just this. Although I developed the model only in a Rawlsian context, we will now see that it can be generalized (cf. Arvan 2008).

First, I proposed that we imagine the parties to the nonideal original position as situated behind a 'nonideal veil of ignorance'-a variant of Rawls's veil of ignorance applied to nonideal conditions instead of strict compliance (Arvan 20I 4: IOO-IO2). For example, in the case of Rawls's theory of domestic justice, the relevant parties to the nonideal original position would all be citizens of a particular state (say, the United States) behind a veil of ignorance applied to the conditions of noncompliance in their society (giving them general knowledge of its injustices). The nonideal veil of ignorance then withholds from the parties any self-identifying information about which citizen (present or future) they might actually be. Consequently, the nonideal original position models a fair method whereby no relevant individuals can arbitrarily privilege themselves in nonideal conditions over anyone else.

Next, I proposed the parties behind the nonideal veil all are to have Rawlsian ideals as all-things-equal motivations (2014: IOO-IO5). This models the fact that Rawlsian ideal theory (if correct) establishes 'conditional' duties of justice. 
Because, as we saw earlier, Rawlsian ideal theory entirely abstracts away from nonideal costs, everyone in the nonideal original position ought to regard themselves under a duty to pursue Rawlsian ideals, but also as free to weigh those ideals against nonideal costs-since again, nothing in Rawlsian ideal theory addressed such costs ( $104-\mathrm{I} O 5$ ). Thus formulated, the nonideal original position superficially appears to contain a contradiction (IO2, IO4). Its parties are all stipulated to have Rawlsian ideals behind the veil, while deliberating as though they could turn out to be any actual individual in nonideal conditions. Because many actual individuals are not motivated by Rawlsian ideals, this seemingly implies that the parties to the model all have motive $X$ (Rawlsian ideals) but might not have $X$-an apparent inconsistency. However, this contradiction is illusory. Because the parties behind the veil are stipulated to deliberate from Rawlsian ideals, the model represents the commonsense idea that justice in a nonideal world requires holding everyone to their duties to pursue a more just world even if, in actuality, they are not motivated to do so (IO4). Putting these two components together-the parties' motives and the nonideal veil of ignorance-I argued that the model represents an important step forward in Rawlsian theory. It provides Rawlsians with a fair procedure for weighing nonideal costs against Rawlsian ideals and for distributing nonideal costs fairly.

Non-Rawlsians might wonder why, if they reject Rawls's original position in ideal theory, they should accept it as a model of fairness in nonideal theory. The answer, I will now argue, is that the nonideal original position represents an attractive model of nonideal fairness relative to diverse ideological and methodological commitments, for the normative rationales for each component of the nonideal original position are perfectly general. The nonideal original position is a compelling model of nonideal fairness not because Rawls's theoretical apparatus implies it, but because it accomplishes several things we should want any nonideal theory of fairness to do, namely:

(I) Hold people normatively to whichever conditional duties of justice they have.

(2) Provide a fair procedure for weighing nonideal costs against those conditional duties and against each other.

(3) Provide a fair procedure for deliberating to substantive principles of fairness for distributing nonideal costs.

We can see this by returning to anti-Rawlsian frameworks. For example, what should a Nozickean be looking for in nonideal theory? As we saw in section I.2, a Nozickean should look to hold everyone to a duty to support libertarian ideals and a principle of rectification, but then they should provide some principled analysis of which nonideal costs it is fair to impose upon people for rectifying historical wrongs. Now consider Marxism. What should a Marxist want in nonideal theory? As we saw in section I.2, they should want to hold everyone in nonideal conditions to a duty to support Communism, while providing some principled analysis of which nonideal costs it is fair to impose upon people in transitioning toward Communism. And what sort of model should a 
'nonideal-theory-only' theorist (e.g., Sen, Wiens, etc.) be looking for? As we saw in section I.3, they should look to hold people to duties to support comparatively more just conditions (qua Sen) or rectify institutional failures (qua Wiens), but then they should provide some principled analysis of nonideal costs it is fair to impose upon people in pursuit of these duties. Finally, what if Gaus (2016) is correct that it is unfair to impose any single set of ideals on people, given the great diversity of views about ideal justice? In that case, we should look to hold people to conditional duties to respect what Gaus calls perspectival diversity (20I6: ch. 3) but then provide some principled analysis of nonideal costs it is fair to impose on people given those duties. In each case, these are the very questions the nonideal original position provides a fair procedure for addressing. Relative to whichever conditional duties one plugs into the model, the nonideal original position models a fair procedure for deliberating to substantive principles of nonideal fairness.

Although in one sense the nonideal original position 'idealizes'-modeling everyone under nonideal conditions in a position of fairness-that does not make it an 'ideal theory'. Any normative theory-including theories of how we should respond to a nonideal world-will have to idealize in some way, telling us what would be fair in a given set of conditions. The salient question, Volacu (2018) points out, is not whether a model idealizes but whether its idealizations accurately represent relevant normative considerations. The point of this article is that the nonideal original position correctly represents normative considerations relevant to determining what is fair in nonideal conditions

The nonideal original position is thus an all-purpose method for engaging in Volacu's (2018) proposed process of 'incremental derivation' in nonideal theory. First, the model can be applied to any set of nonideal conditions-to Rawlsian partial compliance theory, unfavorable conditions theory, or 'no-circumstances-ofjustice theory' (see Arvan 20I4: 98-99), to Simmons's various forms of noncompliance (Simmons 20I0: I7), to unjust international conditions (cf. Arvan 2008), to historical injustices (viz. Nozickean rectification), and so on. Second, it may be applied to specific issues within nonideal theory: to affirmative action, poverty, warfare, and so on. Finally, as we have seen it can be applied using different ideals (Nozickean ideals, Marxist ideals, etc.) or nonideal-theoretic methods (Sen's comparative-justice analysis, Wiens's analysis of institutional failure, etc.).

\section{What Nonideal Fairness Might Be}

Which principles of nonideal fairness might emerge from the nonideal original position? The short answer is that it seems likely to justify different principles for different nonideal conditions-as different conditions (e.g., injustice in modern democracies, injustices in slave states, warfare, etc.) pose different challenges and possibilities. However, there are prima facie reasons to think the principles it is likely to generate will have certain commonalities regardless of nonideal context or which conditional duties are utilized.

To see how, consider how in previous work I filled in the deliberative situation of the parties in the Rawlsian case. First, I argued (Arvan 20I4: IOI-IO8) that because 
ideal theory establishes conditional duties and the veil of ignorance enables the parties to weigh those duties against nonideal costs, the parties have three higher-order interests behind the nonideal veil:

I. Bringing people in nonideal conditions who oppose or are ambivalent to Rawlsian ideals to support and pursue those ideals instead-including the priority relations Rawls (I999a: 53-54) ascribes to his principles of ideal justice.

2. Enabling everyone who has Rawlsian ideals to weigh those ideals rationally against nonideal costs (and nonideal costs against each other).

3. Enabling everyone who weighs Rawlsian ideals rationally against nonideal costs to advance their most favored weighting thereof effectively.

Although these higher-order interests could lead the parties to different principles of nonideal justice for different conditions (e.g., slavery, warfare, etc.), they reveal that the parties have similar deliberative concerns across nonideal contexts: promoting Rawlsian ideals, rationally weighing them against costs, and so on.

Notice, next, that these three interests are highly intuitive vis-à-vis what justice requires in a nonideal world. The first interest tells us that justice requires 'changing the hearts and minds' of people who lack the right ideals. Although in previous work I presupposed Rawlsian ideals, I need not have done so. If we were to build different ideals into the model (e.g., Nozickean ideals, Marxist ideals, etc.), the parties to it would have analogous interests relative to those other ideals: interests in changing people's values in favor of whichever ideals (Rawlsian, Nozickean, Marxist, etc.) one takes to be correct. This implication of the model is highly intuitive: bringing people to support the right ideals has been the aim of (roughly) every reform movement in history. Now consider the second higher-order interest. It tells us that people in nonideal conditions have legitimate interests in rationally weighing ideals against nonideal costs and nonideal costs against each other. This too is highly intuitive. Whether it be affirmative action, reparations, or warfare, one major point of debates about justice in a nonideal world is how people should weigh just end results (e.g., reparations, fair equality of opportunity, etc.) against costs. Finally, the third interest tells us that nonideal justice involves enabling everyone who has the right ideals to have a (fair) say over the costs people should have to face for the sake of bringing about a better world. This is intuitive, too, as fairness must take into account everyone's legitimate interests, not arbitrarily privileging some people's interests over those of others (though, as we will see, the parties may have fair grounds, given the veil, for favoring some people's interests).

Here, then, is the key point: the same rationales for analogous higher-order interests exist relative to whichever normative framework we plug into the model (Nozickean libertarianism, Marxism, 'nonideal-theory-only' frameworks, and so on). Given that, as we have seen, we can attach any of these normative frameworks to the model-let us call whichever theory is plugged-in Theory T-the 
higher-order interests the parties to any nonideal original position should have are these:

I. Bringing people in nonideal conditions who oppose or are ambivalent to Theory $\mathrm{T}$ to support and pursue the conditional duties affirmed by it ('T-duties')-including any required weightings or priority relations between T-duties.

2. Enabling everyone motivated by T-duties to weigh their T-duties rationally against nonideal costs and different nonideal costs against each other.

3. Enabling everyone who weighs T-duties rationally against nonideal costs to advance their most favored weighting thereof effectively.

As such, the deliberative situation of the parties should be similar irrespective of which normative theoretical framework one plugs into the model, indexing the parties' higher-order interests to that model's normative requirements.

One important issue here is how T-duties may constrain how the parties should interpret their higher-order interests. Consider luck-egalitarianism, which requires minimizing inequalities resulting from certain forms of luck, for example, 'brute bad luck' (see Knight 20I3). If this is luck-egalitarianism's fundamental social-political principle, the parties to a luck-egalitarian nonideal original position should take this T-duty to be a hard constraint that they cannot permissibly weigh against other things. Still, there are reasons to believe that within such a constraint, important further questions about nonideal fairness arise for luck-egalitarians. To see how, consider two principles of nonideal justice that would equally minimize brute bad luck-one principle that minimizes brute bad luck quickly but with immense immediate costs (e.g., violent revolution) and another principle that equally minimizes brute bad luck but more slowly with less severe momentary costs spread out over a much longer period of time (viz. incremental reform). Although both principles may equally minimize the total amount of brute bad luck in the world, there is still a further question of which distribution fairness requires. Finally, although luck egalitarians might attempt to settle this question by other means-perhaps by arguing that luck egalitarianism requires lowering each person's brute bad luck below some threshold (Knight 2013: 930) - the nonideal original position provides a powerful new model for examining what fairness requires here.

Now turn to the next step that my previous work defended in a Rawlsian context. In Arvan (2014: I08-I4), I argued that given their three higher-order interests, the parties to a Rawlsian nonideal original position should seek all-purpose 'nonideal primary goods' for advancing their higher-order interests'. Are there any such goods? I argued there are, and I will now defend additional ones, showing how the model can index them to different normative frameworks.

First, I argued that one nonideal primary good is the opportunity to participate effectively in grassroots social movements organized around Rawlsian ideals (2014: IO8-IO). This, very roughly, is because 'people are power.' If one wants to change 'hearts and minds' in a nonideal world (viz. the parties' first higher-order 
interest) and advance one's favored rational weightings of ideals against costs (viz. their second and third interests), one all-purpose means is to get 'allies'-which grassroots groups provide. Second, I argued that because nothing in Rawls's ideal-theoretic machinery dealt with nonideal costs, we must use the nonideal original position to determine which interests of bystanders (and even members of oppressing classes) are fair to be concerned with in nonideal conditions (20I4: IOI, I04-IO6, III-I2). Next, I argued that because the parties' higher-order interests are to enable anyone who has Rawlsian ideals to promote those ideals, rationally weigh them against costs, and so on, the parties have grounds to treat a kind of qualified openness and inclusivity in grassroots deliberation to be a second nonideal primary good (III-I3). Specifically, the parties have grounds behind the veil to want grassroots deliberation to be open and receptive to anyone demonstrating sincere allegiance to Rawlsian ideals-enabling any such individuals (i.e., 'allies') to have a say on how Rawlsian ideals are promoted, weighed against costs, and so on. Finally, however, I argued there are also grounds for the parties to agree to a principle affording extra bargaining power in grassroots deliberation to victims of injustice in proportion to their level of oppression (II5). This is because every party behind the veil knows that oppressed individuals suffer unjust deprivations-deprivations that, given their Rawlsian ideals, the parties should want to compensate. How might additional bargaining power for the more oppressed be achieved in practice? In a number of ways, including greater proportion of more oppressed individuals in grassroots organizations relative to less oppressed or nonoppressed allies, greater representation in leadership positions, group norms that require 'centering' voices of the more oppressed in debate and deliberation (see Goodkind and Deacon 2004), or even differential voting rights in the group, such as plural votes. Whether some ways of weighting bargaining power are more fair than others (or even unfair) is an important further issue. One possibility I intend to explore in future work is how one substantive requirement defended in this article-that the oppressed and their allies should seek overlapping consensus-might be used to evaluate the fairness of different means of weighting bargaining.

Before examining other nonideal primary goods_ranging from social rights and duties to remedial legal, cultural, and economic goods-notice that although I developed the above arguments in a Rawlsian context, the parties to alternative versions of the model (e.g., a Nozickean version, Marxist one, etc.) have reasons to seek analogous nonideal primary goods. First, just as the parties to a Rawlsian nonideal original position should want to 'change hearts and minds' to favor Rawlsian ideals, parties to a Nozickean nonideal original position should want to change hearts and minds in favor of libertarian ideals; parties to a Marxist version should want to change hearts and minds to favor communist ideals, and so on. Second, just as the parties to a Rawlsian version of the model should regard open and inclusive Rawlsian grassroots groups as all-purpose means for advancing their higher-order interests, parties to a Nozickean version should regard open and inclusive libertarian groups as all-purpose means for doing so relative to their ideals, and so on. 
Although my arguments for these 'social' nonideal primary goods may be debated-and I defend additional nonideal primary goods below-the general point is that irrespective of which normative framework the nonideal original position is attached to, its parties have rational grounds to seek certain types of all-purpose goods: specifically, goods for advancing three higher-order interests indexed to their T-duties. Several points here are important.

First, the 'social' nonideal primary goods identified so far seem independently attractive. Grassroots movements and deliberation have long been identified as a primary nexus of nonideal justice. For instance, liberals tend to identify racial and gender justice with the aims of various civil rights movements; Marxists tend to identify nonideal justice with the aims of Communist revolutionary groups; libertarians with fiscally conservative grassroots movements (e.g., the 'Tea Party'), and so on.

Second, the nonideal primary goods defended so far have important normative implications. For example, one long-standing question of procedural fairness is whether and to what extent social activism should be open and inclusive. During the I960s civil rights movement, whereas Martin Luther King Jr. advocated for including whites in activism-while also calling out those who upheld injustice or stood on the sidelines (King I963)-many in the Black Power movement advocated against inclusivity (see Ture I967). Similar debates continue today (e.g., Desmond-Harris 2017; Pollitt 2017). Irrespective of whether my arguments from the model to openness and inclusivity are sound-though I believe they are-the more central point is that the nonideal original positions offers a powerful all-purpose method for rigorously investigating what fairness requires here.

Third, the model can be used to derive procedural and substantive requirements for another class of social nonideal primary goods: interpersonal rights and duties. Such rights and duties have long been at the center of feminist theory and activism, as reflected in arguments for rights to freedom from epistemic injustice (see Fricker 2007; Kidd et al. 2017) and for duties to trust particular standpoints or forms of testimony (Khader 2017; McKinnon 2017). Further, such rights and duties can clearly advance the three higher-order interests of the parties to the model-viz. pursuing their T-duties, enabling people to weigh $\mathrm{T}$-duties rationally against nonideal costs, etc. However, the parties to the model should not know behind the veil which particular social rights and duties they might favor. The reason why is simple: not everyone the parties represent in nonideal conditions has the same views or accepts the same arguments about which social rights and duties best advance their higher-order interests. Consequently, instead of agreeing upon a determinate list of social rights and duties, the parties behind the veil appear to have grounds for favoring a fair real-world procedure for settling which social rights and duties people have: a procedure giving every individual a fair say over which rights and duties people have. We also already have the beginnings of what the parties should take such a procedure to be: open and inclusive grassroots deliberation guided by the parties' T-duties and affording extra bargaining power to the oppressed. Why? Again, because such a procedure would, if implemented, give every person the parties might represent opportunities to have a say in activist deliberation over what people's rights and duties should be, given their T-duties 
and nonideal costs. Finally, as we will now see, the parties also have grounds to favor a further substantive requirement to help ensure deliberation generates rights and duties fair to all.

Recall that the parties are to deliberate behind the veil as though they could be anyone in nonideal conditions motivated by T-duties: not just members of oppressed populations, but also bystanders and sympathetic members of oppressing classes - 'allies' to the oppressed who also face nonideal costs (of social reform) they would never face in ideal conditions. Because the parties deliberate on the assumption that they could be any such individuals-and will not want to have their interests ignored or dominated once the veil is raised-the parties have grounds to want no subgroup's interests to dominate the others. To be clear, the parties do have compensatory grounds to afford extra bargaining power to the oppressed to compensate for oppression. The point is simply that relative to that extra bargaining power, the parties have grounds to want deliberation to result in an overlapping consensus (see Rawls I993: part 2, lecture 4): specifically, agreements on social rights and duties that no one, neither the oppressed nor their allies, considers unfairly exploitative.

Four points are important here. First, notice how well the basic procedural element of this account-settling social rights and duties by grassroots deliberation-coheres with how activism is already widely understood. Grassroots activism, ranging from historical civil rights movements to \#MeToo, has long focused on precisely these issues: that is, on publicly debating, negotiating, and enforcing which social rights and duties people have in combatting injustice (e.g., Desmond-Harris 20I7). Second, if I am correct, the model justifies important procedural and substantive constraints on activism to ensure no one is treated unfairly. It requires activism to be open and inclusive to all those who demonstrate commitment to their T-duties and for activism to seek consensus agreements on social rights and duties, albeit ones 'tugged' substantially in the direction of the interests of oppressed via extra bargaining power (viz. by means outlined earlier). Third, although my arguments to these conclusions may be debated-raising important further questions about how to ensure that the interests of the oppressed are prioritized rather than displaced by the interests of more privileged allies (or worse) - the most relevant point again is that the model provides a powerful new framework for rigorously examining what fairness requires here. Finally, as we will now see, the parties also have grounds to seek several additional nonideal primary goods: remedial legal, economic, and cultural protections.

Consider the National Labor Relations Act (NLRA) of I935, which created legal rights and procedures designed to correct 'inequality of bargaining power between employees who do not possess full freedom of association or actual liberty of contract and employers' (NLRA I935: Title 29, Ch. 7, Subchapter II U.S.C., \I5I). Similarly, consider the Civil Rights Act of I964, which created laws and procedures to protect US citizens against unfair discrimination. Neither act of Congress would presumably be necessary in an ideal Rawlsian society that strictly complied with Rawls's two principles of ideal justice. Instead, the NLRA and Civil Rights Act afford people remedial legal rights and opportunities-ones that serve 
to advance all three higher-order interests of the parties to a (Rawlsian) nonideal original position. First, the NLRA and Civil Rights Act both plausibly promote Rawlsian ideals of economic fairness and equal basic rights and liberties (higher-order interest I). Second, both acts created institutions-the National Labor Relations Board and US Commission on Civil Rights-whose roles include disseminating information about the remedial rights and opportunities established. Insofar as such information is an all-purpose means for people to weigh nonideal costs rationally against Rawlsian ideals, both acts advance the parties' second higher-order interest. Finally, the NLRA and Civil Rights Act give people all-purpose legal means for advancing their favored weighting of Rawlsian ideals against nonideal costs (higher-order interest 3 ). For example, the NLRA does not require people to utilize the legal rights and opportunities it provides. Rather, it affords all citizens legal rights and opportunities to pursue unionization if they judge the nonideal costs to be worth it. The Civil Rights Act serves similar functions for combatting discrimination. Whether these particular acts of Congress advance the parties' higher-order interests better than all other alternative remedial legal rights requires further investigation. The relevant points for now are that the parties clearly should pursue some such remedial legal goods, and the model provides a formal framework for evaluating which remedial rights best advance the parties' interests given the veil.

These implications are important. First, they cohere with the fact that remedial legal rights and opportunities have been implemented in the United States and elsewhere for broadly the reasons identified by the model. Second, the nonideal original position is a powerful model justifying different remedial legal rights and opportunities across different nonideal contexts and ideological frameworks. For example, in previous work I suggested that parties to an international nonideal original position have grounds to agree upon a higher-order human right: very roughly, a right of oppressed peoples to determine collectively, through fair international institutions (e.g., UN consultation), the costs they should face for the sake of promoting their first-order human rights (see Arvan 2008: chs. 3-4). If correct, this could be an important contribution to international theory and practice - as such a right might serve, if embedded in international law and practice, to protect oppressed peoples against unfair forms of 'humanitarian' intervention (2008: 165-66; to take one example, one of many justifications the United States gave for its 2003 invasion of Iraq was the right of the Iraqi people to freedom from tyranny). Third, as we will now see, the nonideal original position justifies different remedial legal rights and opportunities depending on which normative framework we conjoin with it.

For example, suppose Nozickean libertarianism is correct, and we plug libertarian T-duties into the model: duties to rectify historical injustices and respect individual liberty. Given these motives, the parties to a Nozickean version of the model have grounds to reject the National Labor Relations Act as a remedial legal right, at least in its current form. This is because central features of the NLRA are fundamentally inimical to respect for individual liberty. For one thing, the NLRA makes a majority vote to unionize legally binding on all employees in a bargaining unit, restricting the liberty of those who would prefer to 
opt out (NLRA 1935: Sec. 9, $\mathbb{S}$ I59, a \& b). Although the parties to a Nozickan nonideal original position might consider this restriction on liberty given their T-duty to rectify historical injustice, it nevertheless conflicts with their conditional T-duty to respect individual liberty. Consequently, the parties to the Nozickean model have grounds to consider alternatives to the NLRA that might rectify injustice while better respecting liberty. One alternative might be a revised version of the NLRA-one creating legal rights and opportunities to unionize but also legal rights for individuals to opt out. Although this alternative might undermine the effectiveness of collective bargaining (viz. rectification), it would better respect individual liberty. Consequently, the parties to the Nozickean model should probably consider both alternatives (as well as any other relevant alternatives) and decide which to favor by reference to whichever decision-making rule-maximin or otherwise-is rational given the veil of ignorance. By a similar token, parties to a Marxist nonideal original position should presumably seek very different remedial legal rights and opportunities. Given their Communist ideals, they should plausibly favor something like an 'Employee Ownership Act' designed to increase worker ownership of corporations while giving people legal rights and opportunities to influence the nonideal costs they face in the process.

Finally, the parties have clear grounds to seek 'economic and cultural' nonideal primary goods-remedial policies and institutions designed to provide all-purpose cultural and economic support for effectively utilizing their other nonideal primary goods. One plausible institutional example is the NAACP Legal Defense and Educational Fund, a nongovernmental social institution that provides unjustly marginalized populations with legal, educational, and economic assistance in areas ranging from affirmative action to coalition building, policy research, voting, fair housing, and criminal justice. A plausible policy example is welfare for the unemployed - which parties to a Rawlsian nonideal original position should presumably want to promote Rawlsian ideals (viz. fair equality of opportunity); parties to a Nozickean version might favor the policy for rectification but want to tailor it to libertarian ideals (viz. their T-duty to respect liberty), and so on.

Because the creation and maintenance of remedial legal, cultural, and economic goods carry nonideal costs of their own, the parties to the nonideal original position should deliberate about these matters as well. Two obvious possibilities present themselves here. First, the parties might agree upon priority relations among nonideal primary goods. For instance, insofar as grassroots activism is an all-purpose method for individuals to influence the costs they should endure for creating remedial legal, economic, and cultural protections, the parties might favor prioritizing their social primary goods (i.e., fair grassroots deliberation). A second possibility is the parties might use a particular decision-making rule (e.g., maximin) to decide these matters, holding that nonideal primary goods should be distributed in whichever way is maximally advantageous to the most oppressed.

Further development of these ideas must wait for another day. The point for now is that there are systematic reasons to believe that the nonideal original position is an attractive and powerful model for deriving procedural and substantive principles of nonideal fairness relative to whichever broader normative framework it is conjoined with. 


\section{Conclusion}

This article argued that fairness is normatively central to nonideal theory. It then argued that diverse theorists have grounds to adopt a new method for investigating nonideal fairness: a 'nonideal original position'. Finally, this article outlined grounds for believing the model can be used to derive principles of nonideal fairness indexed to different normative frameworks and nonideal contexts-principles that cohere with moral common sense, the history of activism, and contemporary legal practice while also promising more controversial forms of normative guidance. For these reasons, I submit that theorists of diverse backgrounds should take interest in and examine the model further in future research.

MARCUS ARVAN

UNIVERSITY OF TAMPA

marvan@ut.edu

\section{References}

Alexander, M. (20I2) The New Jim Crow: Mass Incarceration in the Age of Colorblindness. New York: The New Press.

Appiah, K. A. (20II) “"Group Rights” and Racial Affirmative Action'. The Journal of Ethics, I 5 , $265-80$.

Arvan, M. (2008) 'A Non-Ideal Theory of Justice'. PhD diss., University of Arizona.

Arvan, M. (20I4) 'First Steps Toward a Nonideal Theory of Justice'. Ethics \& Global Politics, 7, 95-II7.

Arvan, M. (2016) Rightness as Fairness: A Moral and Political Theory. London: Palgrave Macmillan.

Beauchamp, T. L. (1998) 'In Defense of Affirmative Action'. The Journal of Ethics, 2, I43-58.

Bentele, K. G., and E. E. O'Brien. (2013) 'Jim Crow 2.0? Why States Consider and Adopt Restrictive Voter Access Policies'. Perspectives on Politics, I I, I०88-I I6.

Burns, P., and J. Schapper. (2008) 'The Ethical Case for Affirmative Action'. Journal of Business Ethics, 83, 369-79.

Carcien, M. D. (20I0) 'Rawls and Reparations'. Michigan Journal of Race \& Law, I 5, 268-3 I6.

Coates, T. (20I4) 'The Case for Reparations'. The Atlantic, June issue. https://www.theatlantic.com/ magazine/archive/20I4/06/the-case-for-reparations/36I63I/. Accessed Io/6/20I8.

Daniels, N. (1985) Just Health Care. Cambridge: Cambridge University Press.

Desmond-Harris, J. (2017) 'Doubts About Inclusive Feminism Have Little To Do With The Women's March: They're Rooted In History'. Vox. https://www.vox.com/identities/20I I/I/25/I 4355302/ womens-march-feminism-intersectionality-women-of-color-white-feminists. Accessed 9/29/ 2018.

Dworkin, R. (I993) 'Justice in the Distribution of Health Care'. McGill Law Journal, 38, 883-98.

Dworkin, R. (2002) Sovereign Virtue: The Theory and Practice of Equality. Cambridge, MA: Harvard University Press.

Elster, J. (I978) 'Exploring Exploitation'. Journal of Peace Research, I 5, 3-17.

Erman, E., and N. Möller. (20I3) 'Three Failed Charges against Ideal Theory'. Social Theory and Practice, 39, 19-44.

Espindola, J., and M. Vaca (20I4) 'The Problem of Historical Rectification for Rawlsian Theory'. Res Publica, 20, 227-43.

Farrelly, C. (2007) 'Justice in Ideal Theory: A Refutation'. Political Studies, 55, 844-64.

Fricker, M. (2007) Epistemic Injustice: Power \& the Ethics of Knowing. Oxford: Oxford University Press. 
Gaus, G. (2016) The Tyranny of the Ideal: Justice in a Diverse Society. Princeton, NJ: Princeton University Press.

Goodkind, J. R., and Z. Deacon. (2004) 'Methodological Issues in Conducting Research with Refugee Women: Principles for Recognizing and Re-centering the Multiply Marginalized'. Journal of Community Psychology, 32, 72 I-39.

Harris, L. C., and U. Narayan. ([1994] 2007) 'Affirmative Action and the Myth of Preferential Treatment: A Transformative Critique of the Terms of the Affirmative Action Debate'. In H. LaFollette (ed.), Ethics in Practice: An Anthology, 3 d ed. (Malden: Blackwell), 492-504.

Hart, H. L. A. (I955) 'Are There Any Natural Rights?'. The Philosophical Review, 64, I75-91.

Horowitz, D. (200I) 'Ten Reasons Why Reparations for Blacks is a Bad Idea for Blacks—and Racist, too'. FrontPageMagazine.com, reprinted in The Black Scholar: Journal of Black Studies and Research, 3 I, 48 .

Jacobs, L. (I996) 'Can an Egalitarian Justify Universal Access to Health Care?'. Social Theory and Practice, 22, 3 I 5-48.

Kang, H. R. (20I6) 'Can Rawls's Nonideal Theory Save his Ideal Theory?'. Social Theory and Practice, 42, 32-56.

Kant, I. ([1785] 1996) Groundwork of the Metaphysics of Morals. In M. J. Gregor (ed.), The Cambridge Edition of the Works of Immanuel Kant: Practical Philosophy (Cambridge: Cambridge University Press), 38-108.

Khader, S. J. (20I7) 'Transnational Feminisms, Nonideal Theory, and “Other” Women's Power'. Feminist Philosophy Quarterly, 3, I-24.

Kidd, I. J., J. Medina, and G. Pohlhus Jr. (2017) The Routledge Handbook of Epistemic Injustice. New York: Routledge.

King Jr., M. L. ([1963] 20I 2) 'Letter from Birmingham Jail.' Reprinted in Liberating Faith: Religious Voices for Justice, Peace, \& Ecological Wisdom (Lanham, MD: Rowman \& Littlefield), I77-87.

Knight, C. (2013) 'Luck Egalitarianism'. Philosophy Compass, 8, 924-34.

Kocher, R. P., and E. Y. Adashi. (20I I) 'Hospital Readmissions and the Affordable Care Act: Paying for Coordinated Quality Care'. Journal of the American Medical Association, 306, I794-95.

Korsgaard, C. (1996) Creating the Kingdom of Ends. Cambridge: Cambridge University Press.

Krishnamurthy, M. (2OI2) 'Reconceiving Rawls's Arguments for Equal Political Liberty and Its Fair Value'. Social Theory and Practice, 38, 258-78.

Krishnamurthy, M. (2013) 'Completing Rawls's Arguments for Equal Political Liberty and its Fair Value: The Argument from Self-respect'. Canadian Journal of Philosophy, 43, 179-205.

Lawford-Smith, H. (20I0) 'Debate: Ideal Theory-A Reply to Valentini'. Journal of Political Philosophy, I8, 357-68.

Marx, K. ([189I] 2008) Critique of the Gotha Program. Rockville, MD: Wildside Press.

Marx, K., and F. Engels. ([I 848] 2009) The Economic and Philosophic Manuscripts of I 844 and the Communist Manifesto. Translated by M. Milligan. Amherst, NY: Prometheus Books.

Matthew, D. C. (20I5) 'Rawlsian Affirmative Action'. Critical Philosophy of Race, 3, 324-43.

McKinnon, R. (20I7) 'Allies Behaving Badly: Gaslighting as Epistemic Injustice'. In I. J. Kidd, J. Medina, and G. Pohlhus Jr. (eds.), The Routledge Handbook of Epistemic Injustice (New York: Routledge), I67-74.

Mickelson, R. A. (2003) 'When Are Racial Disparities in Education the Result of Racial Discrimination? A Social Science Perspective'. Teachers College Record, I05, I052-86.

Mill, J. S. ([I86I] 200I) Utilitarianism. 2d ed. Edited by G. Sher. Indianapolis, IN: Hackett.

Mills, C. (I997) The Racial Contract. Ithaca, NY: Cornell University Press.

Mills, C. (2005) “"Ideal theory” as Ideology'. Hypatia, 20, I65-84.

Mills, C. (2017) Black Rights / White Wrongs: The Critique of Racial Liberalism. Oxford: Oxford University Press.

Mulligan, T. (20I7) 'Uncertainty in Hiring Does Not Justify Affirmative Action'. Philosophia, 45, I 299-I3 I I.

NLRA. (I935) National Labor Relations Act of I 935 . https://www.nlrb.gov/how-we-work/nationallabor-relations-act. Accessed I/25/20I9.

Nozick, R. (1974) Anarchy, State, and Utopia. New York: Basic Books. 
Pettit, B., and B. Western. (2004) 'Mass Imprisonment and the Life Course: Race and Class Inequality in US Incarceration'. American Sociological Review, 69, I 5 I-69.

Phillips, M. (I985) 'Reflections on the Transition from Ideal to Non-Ideal Theory'. Nous, I9, $55 \mathrm{I}-7 \mathrm{O}$.

Piketty, T., and E. Saez. (2006) 'The Evolution of Top Incomes: a Historical and International Perspective'. American Economic Review, 96, 200-205.

Pojman, L. P. (I998) 'The Case Against Affirmative Action'. International Journal of Applied Philosophy, I2, 97-I I 5 .

Pollitt, K. (20I7) 'Can Feminism Be Too Inclusive?'. The Nation. https:/www.thenation.com/article/ can-feminism-be-too-inclusive/. Accessed 9/29/20I 8.

Rappaport, H. (r999) Joseph Stalin: A Biographical Companion. Santa Barbara, CA: ABC-CLIO.

Rawls, J. (I964) 'Legal Obligation and the Duty of Fair Play'. In S. Freeman (ed.), John Rawls: Collected Papers (Cambridge, MA: Harvard University Press), I I7-29.

Rawls, J. (1993) Political Liberalism. New York: Columbia University Press.

Rawls, J. (I999a) A Theory of Justice: Revised Edition. Cambridge, MA: The Belknap Press of Harvard University Press.

Rawls, J. (1999b) The Law of Peoples, with 'The Idea of Public Reason Revisited'. Cambridge, MA: Harvard University Press.

Rawls, J. (200I) Justice as Fairness: A Restatement. Edited by E. Kelly. Cambridge, MA: Harvard University Press.

Sen, A. (2009) The Idea of Justice. Cambridge, MA: The Belknap Press of Harvard University Press.

Simmons, A. J. (2010) 'Ideal and Nonideal Theory'. Philosophy \& Public Affairs, 38, 5-36.

Singer, P. (I972) 'Famine, Affluence, and Morality'. Philosophy \& Public Affairs, I, 229-243.

Song, S. (2010) 'Mortality Consequences of the 1959-I96I Great Leap Forward Famine in China: Debilitation, Selection, and Mortality Crossovers'. Social Science \& Medicine, 7I, 55 I-58.

Stemplowska, Z. (2008) 'What's Ideal About Ideal Theory?'. Social Theory and Practice, 34, 3I9-40.

Taylor, R. S. (2009) 'Rawlsian Affirmative Action'. Ethics, I I9, 476-506.

Ture, K. (I967) Black Power: The Politics of Liberation. New York: Vintage Books.

Valentini, L. (20I2) 'Ideal vs. Nonideal Theory: A Conceptual Map'. Philosophy Compass, 7 , $554-64$.

Volacu, A. (2018) 'Bridging Ideal and Non-Ideal Theory.' Political Studies, 66, 887-902.

Wenar, L. (2003) 'What We Owe to Distant Others'. Politics, Philosophy and Economics, 2, 283-304.

Wiens, D. (2OI 2) 'Prescribing Institutions Without Ideal Theory.' Journal of Political Philosophy, 20, $45-70$.

Wiens, D. (2015) 'Against Ideal Guidance.' Journal of Politics, 77, 433-46.

Williams, D. R., and P. B. Jackson. (2005) 'Social Sources of Racial Disparities in Health.' Health Affairs, 24, 325-34. 